\title{
PENGUATAN KINERJA BUDIDAYA TAMBAK DALAM RANGKA PENCAPAIAN KETAHANAN PANGAN
}

\author{
Eko Joko Lelono ${ }^{1}$ dan Indah Susilowati ${ }^{2}$ \\ ${ }^{1}$ Fakultas Ekonomi Universitas Tadulako \\ Kampus Bumi Tadulako Tondo Jalan Sukarno Hatta Km. 9 Palu, Sulawesi Tengah 94111 Indonesia \\ Telepon: +62-0451-422611 \\ 2 Fakultas Ekonomi Universitas Diponegoro \\ Jalan Erlangga Tengah Nomor 17 Semarang, Jawa Tengah, Indonesia Telepon +62-024-8453657
}

Diterima 25 September 2010/Disetujui 23 Oktober 2010

\begin{abstract}
This research on production efficiency and availability of brackishwater pond production in Parigi Moutong whether in a state of food insecurity or not. This study used a stochastic frontier production function analysis and cost benefit ratio. As a result, production of aquaculture ponds in the study sites were technically not effective, but feasible to proceed. Cultivation was not efficient because of the positive and significant influence of production inputs of land, seed, and labor. Production inputs such as fertilizer, feed, experience, lime, technology, fisheries counsellor were not significant The availability of pond products produced by processes that have not been efficient and food insecurity due to consumption of fish per capita per year is greater than the amount of production. Strengthening the performance of the pond to achieve food security needs to intensification and diversification. Intensification of land from two crops to be harvested three times a year.
\end{abstract}

Keywords: technical efficiency, cost benefit ratio, aquaculture ponds, stochastic frontier

\begin{abstract}
Abstrak: Penelitian ini mengenai efisiensi produksi produk tambak/brackishwater pond dan ketersediaannya di Parigi Moutong apakah rawan pangan atau tidak. Penelitian ini menggunakan analisis stochastic frontier production function dan ratio biaya manfaat. Hasilnya, produksi dari budidaya tambak di lokasi penelitian secara teknis belum efisien, namun layak diusahakan. Tambak belum efisien karena pengaruh positif dan signifikan dari input produksi lahan, bibit, dan tenaga kerja. Input produksi berupa pupuk, pakan, pengalaman, kapur, teknologi, penyuluh perikanan lapangan tidak signifikan. Ketersediaan produk tambak diperoleh dengan proses yang belum efisien dan rawan pangan karena kebutuhan konsumsi ikan per kapita per tahun lebih besar dibanding jumlah produksi. Penguatan kinerja tambak untuk mewujudkan ketahanan pangan perlu intensifikasi dan diversifikasi. Intensifikasi lahan dari dua kali panen menjadi tiga kali panen setahun.
\end{abstract}

Kata kunci: efisiensi teknis, ratio biaya manfaat, budidaya tambak, stochastic frontier

\section{PENDAHULUAN}

Pangan merupakan pemelihara kebudayaan dan peradaban untuk menjaga kelangsungan hidup bangsa. Tanpa pangan bisa dipastikan sejarah umat manusia akan berakhir. Oleh sebab itu, masalah ketahanan pangan, harus mendapatkan perhatian utama Lebih dari sepa- ruh stok pangan dunia merosot. Tahun 2006 persediaan pangan mampu untuk mencukupi 163 hari kebutuhan dunia. Memasuki semester pertama tahun 2007 diperkirakan tinggal 87 hari. Saat ini, persediaan tersebut dimungkinkan semakin mengecil. Indonesia dengan total penduduk 220 juta jiwa (pertumbuhan penduduk 1,68 persen pertahun) diprediksi menjadi 
260 juta pada tahun 2030, jelas menghadapi problem pangan (Welirang, 2007).

Beras bagi Indonesia menjadi komoditas utama ketahanan pangan di atas 60 persen dari angka kecukupan gizi. komoditas ini menghadapi persoalan lahan garapan perpetani, keterbatasan air irigasi, mahalnya harga input, relatif rendahnya harga produk menjadi faktor pembatas peningkatan kesejahteran dan kemandirian petani, anomali iklim, serta kekurangan persediaan beras diatasi dengan kebijakan mengimpor beras yang sangat berbahaya bagi ketahanan pangan (Nainggolan, 2008). Ketahanan pangan layaknya memenuhi proporsi keperluan makanan sehat dan berimbang mencakup karbohidrat 60-65 persen, lemak 20 persen, protein 15-20 persen dari total kebutuhan perhari (Irianto, 2007).

Berdasarkan pemenuhan keperluan tersebut, maka pengertian ketahanan pangan tidak hanya bersumber dari komoditas karbohidrat saja seperti biji dan umbi-umbian, juga bersumber dari protein hewani dan lemak, seperti ikan.

Ketahanan pangan berkaitan dengan sistem peningkatan produksi menjaga ketersediaan (availability) pangan yang cukup (baik yang bersumber dari domestik maupun impor), terjangkau (accessibility) secara fisik dan ekonomi. Stabil (stability) dalam memenuhi kebutuhan pangan di musim sulit, dan aman (safety) di konsumsi. Ketahanan pangan layaknya memenuhi proporsi keperluan makanan sehat dan berimbang yakni karbohidrat $60-65$ persen, lemak 20 persen, protein $15-20$ persen dari total kebutuhan per hari (Irianto, 2006). Berdasarkan pemenuhan keperluan tersebut, maka pengertian ketahanan pangan tidak hanya bersumber dari komoditas karbohidrat (seperti biji dan umbi-umbian), juga bersumber dari protein hewani dan lemak, seperti ikan.

Indonesia memiliki 18.110 pulau dengan panjang pantai 108.000 kilometer, memiliki potensi ikan (tawar dan tangkap), budidaya laut dan tambak. Di kawasan pesisir terdapat lahan tambak mencapai 913.000 ha, potensi tersebut tahun 2000 telah dimanfaatkan seluas 390.000 ha (42,7 persen), terdiri dari tambak teknologi intensif 86.190 ha dan teknologi sederhana 303.810 ha. Keberadaan tambak saat ini semakin terancam oleh abrasi laut, lahan mangrove semakin susut akibat desakan pemukiman penduduk, karena secara administratif di kawasan pesisir ada 42 kota dan 181 kabupaten yang dihuni sekitar 140 juta jiwa (60 persen dari penduduk Indonesia). (Menteri Permukiman dan Prasarana Wilayah, 2003; Siregar dan Hasanah, 2005; Kusnadi, 2006; dan Atjo, 2006).

Kawasan pesisir mempunyai potensi besar yang secara signifikan telah memberi lapangan kerja bagi masyarakat, karena kontribusi sektor perikanan pada pembangunan nasional sebesar 16,12 persen terhadap PDB dan mampu menyerap tenaga kerja tidak kurang dari 16 juta (Dahuri, 2004; Kusnadi, 2006, dan DKP, 2007).

Produksi perikanan budidaya menurut komoditas utama tahun 2007, di Jawa mencapai 53,78 persen dari total nasional, disusul Sulawesi 27,59 persen, Sumatra 10,39 persen, Kalimantan 5,15 persen, Bali-Nusa Tenggara 2,92 persen dan Maluku-Papua kurang dari 1 persen. Di Sulawesi untuk komoditas dalam tahun yang sama mencapai 1.050.432 ton, tertinggi di Sulawesi Selatan mencapai 68,34 persen, disusul Sulawesi Tengah 19,30 persen, Sulawesi Tenggara 8,87 persen, Sulawesi Utara 1,97 persen, Gorontalo 0,97 persen, dan Sulawesi Barat sebesar 0,52 persen (Statistik Budidaya DKP, 2007).

Di Sulawesi Tengah kontribusi sektor perikanan terhadap total PDRB kurun waktu 20002005, secara rata-rata masih di bawah 10 persen. Rendahnya kontribusi sektor ini pada pembangunan daerah mencerminkan belum maksimalnya pengelolaan sumberdaya lokal yang tersedia (DKP, 2006).

Pertambakan di Sulawesi Tengah mempunyai lahan mencapai 42.095 ha, dan disepanjang kawasan pesisir Teluk Tomini Kabupaten Parigi Moutong potensinya 10.306 ha (tergarap seluas 3.562,50ha atau 34,57 persen), dominan dengan skala usaha kurang dari 2 ha (dikelola 2.466 RTP) dan 2-5 ha dikelola oleh 304 RTP (DKP, 2006). Umumnya tambak di Provinsi ini lebih khusus Kabupaten Parigi Moutong mempunyai hutan bakau sebagai daerah penyangga semakin menipis, karena berbagai keperluan konversi dan abrasi laut. Hasil studi yang dilakukan oleh Suryono (2006) menyebutkan bahwa menyusutnya lahan mangrove dikonversi untuk keperluan tambak dan pemukiman, tetap 
menurunkan nilai ekonomis.

Karakteristik lapangan usaha yang menonjol di kawasan pesisir ini adalah jasa, perdagangan, pertanian, perkebunan, dan usaha budidaya tambak. Kebiasaan sebagian petani tambak merangkap pelaku distribusi, bertani sawah, berkebun coklat, cengkeh, kelapa, dan menjadi nelayan.

Kegiatan budidaya tambak ditujukan untuk mencapai kesejahteraan petani tambak yang tidak bisa dipisahkan dari efisiensi penggunaan sumberdaya yang ada dan keterbatasan pada mereka.

Dilihat dari produktivitas budidaya tambak di daerah ini rata-rata pertahunnya sebesar 1,231 ton/ha/tahun, masih lebih rendah dibanding produktivitas nasional (1996 mencapai 2,5 ton per ha/tahun dan 2004 menjadi 2 ton per ha/tahun) (Komariah, 1996; Dahuri, 2004, dalam Siregar dan Hasanah, 2005). Demikian pula dengan konsumsi ikan perkapita pertahun di Sulawesi Tengah baru mencapai $18,97 \mathrm{~kg} /$ tahun lebih rendah dibanding konsumsi rata-rata per kapita secara nasional 21,82 kg/tahun (DKP, 2005).

Umumnya produk ikan (termasuk bandeng) merupakan bahan makanan mudah rusak (perishable food), yang harus diimbangi dengan kemampuan distribusi yang baik (seperti oleh pelaku, alat transportasi, pendingin, akses jalan, waktu tempuh) sejak dari pemuatan awal di lokasi produksi dalam perjalanan sampai dinikmati oleh konsumen. Pelaku distribusi di daerah ini umumnya dilakukan oleh petani yang bertindak sebagai pedagang pengumpul, meskipun ada yang berprofesi sebagai pedagang pengumpul. Hasil tambak dijemput oleh pengumpul di lokasi produksi, sehingga biaya transportasi dari petani tambak dalam penelitian ini dianggap nol.

Bandeng dari daerah ini sebagian besar dijual di Kabupaten Parigi Moutong, di Kabupaten Poso, ke Palu, Kalimantan dan Papua. Udang sebagian besar dipasarkan ke Makasar. Kebiasaan di daerah ini untuk menjaga kualitas bandeng dan udang, baik petani, pedagang pengumpul maupun pengecer secara tradisional menyimpan produk tambak pada drum (fiberglass/box) yang berisi es dan garam.

Studi budidaya tambak telah banyak dila- kukan, pada penelitian ini melakukan kombinasi faktor input produksi dari Smith (1981), Komariah (1996), dan Pasaribu (2004), dengan menambahkan input baru seperti pengalaman dan penyuluh perikanan lapangan sebagai pembeda. Selanjutnya pada aspek distribusi menelusuri perilaku pedagang pengumpul untuk menganalisis saluran distribusi pemasaran, yang didukung dengan index composite food security (ICFS) produk tambak bandeng dan udang di lokasi penelitian.

Luas lahan budidaya tambak di Sulawesi Tengah mencapai 42.095 ha terluas di Kabupaten Parigi Moutong (10.306 ha, dan digarap mencapai 3.562,50 ha). Di daerah ini dominan skala usaha kurang dari 2 ha (dikelola 2.466 RTP) dan 2-5 ha dikelola oleh 304 RTP.

Produktivitasnya secara rata-rata pernah mencapai 1.231 ton/ha/tahun, masih rendah dibanding nasional (1996 mencapai 2,5 ton/ha/ tahun dan 2004 menjadi 2 ton/ha/tahun). Demikian pula dengan konsumsi ikan perkapita mencapai $18,97 \mathrm{~kg} /$ tahun dibandingkan secara nasional mencapai $21,82 \mathrm{~kg} /$ tahunnya (DKP, 2005)

Rendahnya konsumsi ikan per kapita menunjukkan rendahnya kesejahteraan petani dan rawannya ketersediaan pangan produk tambak di lokasi produksi, kondisi tersebut tidak bisa dipisahkan dari penguasaan teknologi yang digunakan.

Budidaya tambak ditujukan untuk mencapai kesejahteraan hidup yang lebih baik bagi pelakunya, maka upaya tersebut tidak bisa dipisahkan dari efisiensi penggunaan sumberdaya dan keterbatasan yang ada pada mereka. Penggunaan faktor input produksi yang tidak efisien bisa menyebabkan rendahnya produktivitas. Selain faktor tersebut juga karena kebiasaan petani bekerja di luar tambak untuk menambah penghasilan. Upaya ini merupakan sesuatu yang baik, akan tetapi dalam jangka panjang seiring dengan perubahan zaman dan keperluan hidup semakin meningkat, keberadaan lahan tambak terdesak oleh pemukiman. Kecenderungan ini menunjukkan bahwa budidaya tambak tidak bisa dijadikan sandaran hidup satu-satunya bagi mereka.

Berdasarkan fenomena budidaya tambak untuk mencapai ketahanan pangan di lokasi 
penelitian, pertanyaannya adalah apakah budidaya tambak di daerah ini masih dapat dijadikan sandaran hidup? Apakah kombinasi penggunaan faktor input produksi signifikan dalam menjelaskan output tambak?

Untuk menjawabnya perlu penelitian melalui beberapa pertanyaan berikut; Apakah penggunaan faktor input produksi sudah efisien atau belum efisien dalam menghasilkan produk tambak? Apakah saluran distribusi produk budidaya tambak sudah efisien atau belum efisien (dilihat dari sistem saluran distribusi pemasarannya) sampai ke tangan konsumen? Apakah produksi tambak dilihat dari ketersediaan (availibility), keterjangkauan (accessibility) tergolong tahan untuk mendukung ketahanan pangan di daerah penelitian.

Kinerja. Berkenaan dengan kata kinerja, Suhanda (2008) memaknainya sebagai perwujudan dari pelaksanaan uraian tugas (job description) sesuai dengan posisi jabatannya sebagai hasil analisis jabatan pada suatu periode tertentu. Sedang Kunawangsih (2004) melihatnya lebih bersifat multidimensional yang ditentukan oleh berbagai profil ukuran ekonomi, efektifitas dan efisiensi.

Disimpulkan bahwa kinerja merupakan sesuatu yang dicapai melalui pelaksanaan (proses), menyalurkan (distribusi) sampai ke konsumen, dan dapat pula dipahami sebagai sebuah proses terencana bukan sekedar hasil.

Kinerja bisa dilihat dari lingkup ketahanan pangan ada tiga kegiatan ekonomi yang saling berhubungan yakni ketersediaan (availability) dan kecukupan menjadi bagian dari aspek produksi; terjangkau (accessibility) secara ekonomi dan tempat dibahas pada aspek distribusi dan aspek konsumsi; stabilitas (stability) masih terkait dengan aspek distribusi dan aspek konsumsi; dan aman (safety) di konsumsi berhubungan dengan aspek konsumsi.

Budidaya Tambak. Budidaya tambak terdiri dari kata budidaya dan kata Tambak, Hermanto (2007) menjelaskan kata budidaya berasal dari bahasa Inggris "aquaculture" yang berarti pengusahaan organisme akuatik. Tambak merupakan habitat budidaya air payau yang berlokasi di daerah pesisir. Secara umum tambak digunakan untuk memelihara udang windu, ikan bandeng, ikan nila, ikan kerapu, kakap putih, dan sebagainya. Udang windu memiliki nilai ekonomis tinggi karena berorientasi ekspor, membuat pengusaha tanpa pengalaman tertarik membuka lahan baru dengan tidak memperhitungkan kelestarian lingkungan. Pengelolaan kawasan pesisir yang tidak benar, menimbulkan masalah penurunan mutu lingkungan pesisir yang berdampak pada produktivitas lahan dan kelangsungan hidup kegiatan budidaya. Konsep pembangunan tanpa koordinasi menimbulkan benturan, karena daerah pesisir terkait dengan tata ruang, sosial budaya, keamanan dan ekonomi masyarakat.

Pembabatan hutan bakau (mangrove) semakin serius akan ganggu keberlanjutan usaha, karena tak ada lagi penghalang terjangan air pasang. Giyanto (2008) menjelaskan bahwa pentingnya penanaman pohon bakau sebagai pengendali abrasi. Pengalaman disekitar desa Kartikajaya Kabupaten Kendal Jawa Tengah selama sepuluh tahun terakhir ini tidak kurang 380 hektar tambak hilang, dan jika tidak ditanami pohon bakau, bisa jadi abrasi akan merusak ke pemukiman penduduk. Selain untuk penghalang, pohon bakau juga berfungsi sebagai penyerap dan penetralisir racun di air tambak.

Budidaya tambak memerlukan strategi musim tanam yang tepat sebagai salah satu keberhasilan dalam produksi. BBPBAP Jepara, menjelaskan kegagalan (panen premateur) akibat petani salah dalam memilih waktu tanam. Di Indonesia ada dua musim (kemarau dan penghujan), perlu kecermatan untuk memprediksi peluang keberhasilan yang maksimal. Pentingnya informasi musim ini agar petani tambak: (1) dapat mengoptimalkan lahan dalam musim tanam yang tepat; (2) agar memperoleh hasil produksi yang optimal; dan (3) dapat memperoleh keuntungan.

Pusat data dan informasi (DKP, 2008) menjelaskan target produksi budidaya tahun 2007 tidak tercapai karena terbatasnya dukungan permodalan (dana APBN terbatas), sarana dan prasarana pendukung produksi budidaya (seperti saluran tambak dan balai benih), dan musibah banjir. Meskipun demikian, produksi perikanan budidaya periode 2003 hingga 2007 mengalami kenaikan yang cukup signifikan dari 1.224.192 ton pada 2003 menjadi 3.088.800 
ton tahun 2007. Periode 2006-2007 produksi perikanan hanya naik 15,14 persen dari target 36,32 persen. Peningkatan produksi ini cenderung karena penerapan teknologi, perluasan areal budidaya, dan pengadaan berbagai jenis benih yang berkualitas, untuk mendukung keinginan tersebut perlu dibangun dan dikembangkan balai benih ikan sebagai mata rantai pertama dalam sektor produksi usaha budidaya ikan.

Ketahanan Pangan. Studi tentang ketahanan pangan fokusnya pada ketersediaan pangan yang umumnya diukur dengan tingkat konsumsi beras nasional. Tingkat konsumsi beras tahun 2002 mencapai 121,6 kg/kapita dan terpenuhi dari produksi dalam negeri sebesar 107,5 persen, sekitar 14,1 persen kebutuhan dalam negeri ditopang oleh impor. Jika diukur dalam satuan energi dan protein sebesar 2992 Kkal/kapita/hari dan 80 gram protein/kapita/ hari (Suryana, 2002; Supardi 2004; FAO, 2004, dan Darwanto, 2005)

Keperluan pangan perorang perhari karbohidrat mencapai 60-65 persen, lemak 20 persen, protein 15-20 persen. Karbohidrat adalah pangan pokok sumber energi yang komoditasnya adalah beras, jagung, gandum, umbi, dan bijian. Lemak adalah zat pembangun yang sumber komoditasnya lauk-pauk seperti ikan, telur, ayam, daging, susu, lainnya. Protein adalah zat pengatur yang sumber komoditasnya meliputi sayur dan buah-buahan (Yusuf et al., 2008, dan Irianto, 2007).

Dominannya karbohidrat sebagai sumber utama ketahanan pangan karena beberapa alasan. Pertama, ditinjau dari total keperluan pangan per kapita per hari untuk proporsi makanan sehat dan berimbang, di atas 60 persen (Nainggolan, (2008). Kedua, komoditasnya tersebut hasilnya mudah diperkirakan karena menggunakan input produksi seperti bibit, pupuk, tenaga kerja, modal kapital, saluran irigasi, pentingnya mengenal iklim, kemampuan manajerial, dan keberadaan tenaga penyuluh pertanian.

Pertanyaannya adalah mengapa produk budidaya tambak tidak terkenal seperti karbohidrat. Mengacu pada pertanyaan tersebut, karena: (i) kontribusi komoditas ini untuk pemenuhan keperluan hidup seimbang per kapita mencapai 20 persen perhari. Pada hal proses produksi ikan dan bandeng menggunakan input yang dapat diprediksi hasilnya. (ii) manfaat ikan, menurut Efendi (2008) mempunyai kandungan gizi sangat banyak dan penting seperti asam lemak yang dikenal dengan omega-3. Kebiasaan mengkonsumsi ikan pada masyarakat Eskimo dan Jepang memberi petunjuk kuat sangat rendahnya kejadian penyakit jantung dan penyakit degeneratif lainnya.

Berdasarkan pandangan tersebut, penelitian ini dapat dilakukan pada komoditas ikan khususnya bandeng dan udang, karena beberapa alasan: (i) faktor kepemilikan sumberdaya. Kepemilikan sumberdaya menurut Fauzi (2004) dibedakan atas kepemilikan komunal dan kepemilikan privat. Kepemilikan komunal seperti pada sumberdaya laut, bisa dimiliki atau dimasuki oleh siapapun dalam menangkap ikan yang hanya dibatasi oleh aturan kedaulatan negara dan konvensi, dibanding dengan kepemilikan privat (individu/swasta), misalkan seperti budidaya di wilayah pesisir (laut, tambak), di danau, dan kolam; (ii) karena permintaan pasar global terhadap komoditas ikan akan terus bertambah, seperti yang diperkirakan bahwa menurut Msangi (2005) total food fish global per capita food consumtion 1997 15,8 kg/person/ year and $202017,1 \mathrm{~kg} /$ person/year."

Bercermin pada ketersediaan beras nasional lebih kecil dibanding dengan keperluan dalam negeri, perlu sebuah strategi penguatan ketahanan pangan sejak dari aspek produksi. Seperti ketersediaan pangan di produksi dari lahan semakin sempit, petani gurem (luas garapan $<0,5 \mathrm{ha}$ ) terus meningkat dari 10,7 juta (1993) menjadi 13,3 juta KK (2003). Petani ini mempunyai aksesibilitas yang terbatas pada sumber permodalan, teknologi, dan sarana produksi, sehingga sulit meningkatkan efisiensi dan produktivitas tanpa difasilitasi pemerintah. Peningkatan kapasitas kelembagaan petani, serta peningkatan kualitas penyuluhan ${ }^{1}$ merupakan tantangan pembangunan ketahanan pangan ke depan. Dilihat dari aspek distribusi, tidak bisa diharap sistem distribusi yang efisien jika prasarana distribusi darat dan antarpulau hingga saat ini belum memadai. Karena sistem

1 Diadaptasi dari hasil penelitian yang telah diseminarkan di Portklang Selangor, Rahim M.Sail (2008) 
distribusi yang efisien menjamin seluruh rumah tangga dapat memperoleh pangan dalam jumlah dan kualitas yang cukup sepanjang waktu, dengan harga terjangkau (Nainggolan, 2008)

Memperhatikan lingkup ketahanan pangan ada tiga kegiatan ekonomi yang saling berhubungan yakni ketersediaan (availability) dan kecukupan menjadi bagian dari aspek produksi; terjangkau (accessibility) secara ekonomi dan tempat dibahas pada aspek distribusi dan aspek konsumsi; stabilitas (stability) masih terkait dengan aspek distribusi dan aspek konsumsi; dan aman (safety) dikonsumsi berhubungan dengan aspek konsumsi.

Teori Perilaku Produsen. Menurut Partomo (2008) kajian ekonomi industri meliputi proses produksi distribusi sampai kepada konsumen melalui mekanisme pasar. Terkait dengan penelitian budidaya tambak penekanan teorinya lebih kepada teori ekonomi produksi Neoklasik. Lingkup penelitian ini merupakan studi kasus, maka menurut Smith (1981), arah pertanyaannya apakah penggunaan input signifikan dalam menjelaskan variasi output dari produsen tambak?. Budidaya tambak berproduksi dengan skala ekonomi, apakah petani dalam menggunakan input sudah optimal? Apakah secara teknis sudah efisien? Hambatan apa yang menghalangi peningkatan produktifitas dan profitabilitas dari sistem sumberdaya tambak ini.

Farel (1957) membedakan efisiensi: teknis, alokatif, dan ekonomis. Timmer (1970) mendefinisikan efisiensi teknis sebagai ratio input yang benar-benar digunakan dengan output yang tersedia. Dengan kata lain, besaran yang menunjukkan perbandingan antara produksi sebenarnya dengan produksi maksimum. Kumbhakar dan Lovell (2000²) mengatakan bahwa ada tiga cara memaksimumkan keuntungan dari suatu usahatani. Cara (i) memaksimumkan output pada penggunaan input tertentu atau sering disebut efisiensi teknis; (ii) keuntungan maksimum dapat diperoleh melalui kombinasi input yang sesuai pada tingkat harga input tertentu (efisiensi alokatif); dan (iii) menghasilkan kombinasi produksi yang tepat pada tingkat harga produksi tertentu. Memahami pengertian efisiensi tersebut simpulnya bahwa

2 Diadaptasi dari Sukiyono (2005) efisiensi (baik teknis, alokatif, ekonomi) merupakan indikator kinerja dari usahatani termasuk budidaya tambak. Pencapaian efisiensi teknis (terutama bagaimana petani meminimalkan penggunaan faktor input) yang tinggi bertujuan meningkatkan kompetitif dan keuntungan.

Efisiensi penggunaan faktor-faktor produksi dengan FPF. Efisiensi telah menarik banyak pembuat kebijakan dan ahli ekonomi, efisiensi bisa dimaknai sebagai tepat cara, hemat waktu, hemat tenaga, dan hemat biaya (kamus bahasa Indonesia), sedang menurut Nopirin (1976) tidak ada pemborosan. Efisiensi menurut Yotopoulos dan Nugent (1976), Stoner et al., (1995) dan Adiyoga (1999), adalah transformasi input (tenaga kerja, finansial, alat/teknologi) tertentu untuk mendapatkan output sebesarbesarnya. Berdasarkan pemahaman tersebut efisiensi bisa dimaknai lebih kearah memaksimalkan output dari pada meminimalisasi input.

Farel (1957), membedakan efisiensi: teknik, alokatif, dan ekonomis. Timmer (1970), mendefinisikan efisiensi teknik sebagai rasio input yang benar-benar digunakan dengan output yang tersedia. Dengan kata lain, besaran yang menunjukkan perbandingan antara produksi sebenarnya dengan produksi maksimum. Efisiensi alokatif tercapai jika perusahaan (budidaya tambak) mampu memaksimumkan keuntungan yaitu menyamakan produk marjinal setiap faktor produksi dengan harganya. Sedang efisiensi ekonomi adalah besaran yang memperlihatkan perbandingan antara keuntungan yang sebenarnya dengan keuntungan maksimum. Pengertian lain, efisiensi ekonomi tercapai apabila efisiensi harga dan efisiensi teknis dicapai.

Efisiensi teknis merupakan salah satu komponen dari keseluruhan efisiensi ekonomi. Kumbhakar dan Lovell (2000, dalam Sukiyono, 2005) mengatakan bahwa ada tiga cara memaksimumkan keuntungan dari suatu usahatani. Cara (i) memaksimumkan output pada penggunaan input tertentu atau sering disebut efisiensi teknis; (ii) keuntungan maksimum dapat diperoleh melalui kombinasi input yang sesuai pada tingkat harga input tertentu (efisiensi alokatif); dan (iii) menghasilkan kombinasi produksi yang tepat pada tingkat harga produksi tertentu.

Memahami pengertian efisiensi tersebut 
simpulnya bahwa efisiensi (baik teknik, alokatif, ekonomi) merupakan indikator kinerja dari usahatani (termasuk budidaya tambak). Pencapaian efisiensi teknik (terutama bagaimana petani meminimalkan penggunaan faktor input) yang tinggi bertujuan meningkatkan kompetitif dan keuntungan.

Menurut Adiyoga (1999) pada dasarnya petani tambak ingin memaksimumkan keuntungan, namun dalam berperilaku petani tambak tidak lepas dari perubahan yang terjadi pada lingkungan kerja mereka sehari-hari. Mengelola usahatani (tambak), petani mungkin saja melakukan penyimpangan yang berkonsekuensi. Dinamika budidaya tambak bisa mengubah lingkungan tehnis dan ekonomis terus menerus, sehingga menimbulkan kesulitan bagi petani dalam menyesuaikan keputusan alokatifnya (biayanya) sebagai respon terhadap perubahan dilingkungan produksinya.

Beberapa studi fungsi produksi C-D mengestimasi frontier production function (FPF) adalah oleh Farrel (1957), Richmont (1974), Aigner and Chu (1968, dalam Fattah, 2000), menjelaskan bahwa fungsi produksi frontier dalam operasionalnya mewakili penggunaan teknologi secara luas oleh perusahaan (termasuk budidaya tambak). Model fungsi produksi Cobb-Douglass dapat dituliskan sebagai berikut:

$$
Y_{i}=\sum_{j=0}^{m} a_{j} X_{i j}^{\beta j} e_{i}
$$

di mana: $\mathbf{Y}_{\mathbf{i}}$ adalah output pada sampel ke-i; a adalah intercept (perpotongan); $\mathbf{X}_{\mathbf{i j}}$ adalah input yang digunakan sampel pada pengamatan ke-j; $\mathbf{B}_{\mathbf{j}}$ adalah elastisitas produksi; $\mathbf{e}_{\mathbf{i}}$ adalah faktor kesalahan pada sampel i.

Dalam bentuk logaritma dapat ditulis sebagai berikut:

$y_{i}=\sum_{j=0}^{m} \beta x_{i j}+E_{i}$

di mana: $\mathbf{y}$ adalah $\log \mathrm{Y} ; \mathbf{x}$ adalah $\log \mathrm{X} ; \mathbf{E}$ adalah log e.

Kalau persamaan ini diduga dengan frontiernya, maka $E_{i}$ harus diminimumkan atau dihilangkan, sehingga $\hat{y}_{i} \leq y_{i}$ dengan demikian, maka: $\sum_{j=0}^{m} \beta_{j} \mathrm{x}_{\mathrm{ij}}=\hat{\mathrm{y}}_{\mathrm{i}} \leq \mathrm{y}_{\mathrm{i}}$

Persoalan pada persamaan (2) dapat dituliskan sebagai berikut:

Minimumkan $\sum_{j=i}^{m} E$

Dengan syarat; $\sum_{j=i}^{m} \beta_{\mathrm{j}} \mathrm{x}_{\mathrm{ij}} \geq \mathrm{y}_{\mathrm{i}}$ dan $\beta_{\mathrm{j}} \geq 0$

dengan meminimumkan dan memenuhi persyaratan tersebut, menunjukkan persoalan "linear programming", sehingga $\beta_{j}$ dapat dihitung. Dengan menjumlahkan sampel yang diamati, maka persamaan lengkap dapat ditulis sebagai berikut:

$$
\begin{aligned}
& \sum_{j=1}^{n} \sum_{j=0}^{m}(\beta j \chi i j)-\sum_{i=1}^{n} E i=\sum_{i=1}^{n} y i \\
& \sum_{i=1}^{n} E i=\sum_{j=1}^{n} \sum_{j=0}^{m}(\beta j \chi i j)-\sum_{i=j}^{n} y i
\end{aligned}
$$

di mana - Syi adalah konstan, sehingga dapat di buang dari persamaan, karena menurut Timmer (1971, dalam Fattah, 2000) mengatakan bahwa rata-rata tengah $(\bar{X})$ dari $\mathrm{X}$ dapat dipakai menggantikan nilai persamaan $X$ tanpa bias yang serius, maka persoalan di atas dapat ditulis kembali menjadi:

Minimumkan $\sum_{j=0}^{m} \beta j \bar{x}_{i}$

Dengan catatan $\sum_{j=0}^{m} \beta j x_{i j} \geq y_{j}$

Generalisasi dari persamaan tersebut adalah:

Minimumkan $\beta_{0}+\beta_{1} x_{1}+\beta_{2} x_{2}+\ldots+\beta_{m} x_{m}$

Dengan syarat

$\beta_{0}+\beta_{1} x_{1.1}+\beta_{2} x_{2.1}+\ldots+\beta_{m} x_{m .1} \geq y_{1}$

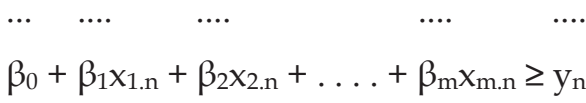

dan $\beta \geq 0$.

di mana $\mathbf{X}_{\mathbf{m}}$ adalah input $\mathrm{m} ; \mathbf{Y}_{\mathbf{n}}$ adalah produksi 
pada sampel ke-n, dan $\boldsymbol{\beta}_{\mathrm{j}}$ adalah besaran yang harus diduga dengan teknik program linier. Selanjutnya sudah dapat ditentukan fungsi produksi frontier dengan mempergunakan model Cobb-Douglas:

$$
Y_{i}=\sum_{j=0}^{m} a_{i} X_{i j}^{\beta j} e_{i}
$$

Berkaitan dengan hal ini, kalau produksi dikalikan dengan harga dan dikurangi biayabiaya maka akan diperoleh besarnya keuntungan. Selanjutnya besarnya efisiensi teknik, efisiensi ekonomi dan efisiensi harga dapat dihitung, atau dengan perkataan lain model fungsi produksi frontier untuk budidaya tambak akan diestimasi dengan Ordinary Least Square (OLS).

Efisiensi yang dibahas dalam penelitian ini ialah efisiensi penggunaan faktor-faktor produksi budidaya tambak seperti bibit, pupuk: urea, pakan, lahan, kapur, tenaga kerja, mempergunakan metode analisis frontier production function (FPF)" dari fungsi produksi C-D.

Frontier production function (FPF) menurut Fattah (2000) adalah fungsi produksi yang dipakai untuk mengukur bagaimana fungsi produksi yang sebenarnya terhadap posisi frontiernya yang terletak pada garis isokuan. FPF memberi kemudahan membedakan tiga jenis efisiensi, efisiensi teknis (ET), efisiensi harga (EH), dan efisiensi ekonomi (EE). ET adalah besaran nilai yang menunjukkan perbandingan antara produksi sebenarnya dengan produksi maksimum, EE adalah besaran yang menunjukkan perbandingan antara keuntungan yang sebenarnya dengan keuntungan maksimum. Efisiensi yang dibahas dalam penelitian ini ialah efisiensi penggunaan faktor-faktor input seperti bibit, pupuk: urea, pakan, lahan, kapur, tenaga kerja, mempergunakan metode analisis frontier production function (FPF)" dari fungsi produksi C-D.

Produksi budidaya tambak di lokasi penelitian diasumsikan sebagai fungsi dari Lahan $\left(X_{1}\right)$, Bibit $\left(X_{2}\right)$, Tenaga Kerja $\left(X_{3}\right)$, Pupuk $\left(X_{4}\right)$, Pakan $\left(X_{5}\right)$, Pengalaman $\left(X_{6}\right)$, Kapur $\left(X_{7}\right)$, Teknologi $\left(D_{1}\right)$, penyuluh perikanan lapangan $\left(D_{2}\right)$. Secara matematis dalam bentuk linier logaritma natural, model produksi frontier untuk budi- daya tambak dapat dituliskan sebagai berikut:

$$
\begin{aligned}
\operatorname{Ln} Y_{i}= & c+a_{1} \operatorname{Ln} X_{1}+a_{2} \operatorname{Ln} X_{2}+a_{3} \operatorname{Ln} X_{3}+ \\
& a_{4} \operatorname{Ln} X_{4}+a_{5} \operatorname{Ln} X_{5}+a_{6} \operatorname{Ln} X_{6}+ \\
& a_{7} \operatorname{Ln} X_{7}+D_{1}+D_{2}+\eta i-u_{i}
\end{aligned}
$$

dimana $\mathbf{i}$ adalah petani ke-i, dan $\mathbf{\eta}_{\mathbf{i}}$ adalah kesalahan acak model serta $\mathbf{u}_{\mathbf{i}}$ adalah variabel acak yang merepresentasikan inefisiensi teknis. Aspek produksi selain diestimasi dengan fungsi produksi frontier, juga dianalisis dengan penerimaan dan pengeluaran untuk mengetahui $\mathrm{R} / \mathrm{C}$ ratio. Rasio ini menunjukkan setiap nilai rupiah yang dikeluarkan dapat memberikan sejumlah manfaat (nilai penerimaan), atau dengan pengertian lain seberapa besar manfaat (keuntungan) yang diperoleh dari pengeluaran uang satu rupiah tersebut.

Saluran Distribusi Pemasaran di Lokasi Penelitian. Saluran distribusi pemasaran dalam mendukung ketahanan pangan terkait dengan kemampuan menyebarkan produk sampai dan terjangkau oleh konsumen. Untuk memahami hal itu seringkali digunakan pendekatan structure-performance-conduct (SPC). Pendekatan struktur (structure) seringkali diarahkan pada distribusi fisik produk tambak di pasar umum. Pendekatan pelaksanaan (performance) di pasar umum fokusnya pada margin pemasaran, dalam sistem pemasaran yang efisien dibicarakan tiga hal, seperti biaya transportasi, biaya penanganan dan keuntungan. Sedang pendekatan pelaksanaan (conduct) terkait dengan pola tingkah laku dalam interaksi pasar, biasanya diarahkan pada cara berjualan dan kebijakan harga.

Umumnya produk ikan (termasuk bandeng dan udang) merupakan bahan makanan mudah rusak (perishable food), yang harus diimbangi dengan kemampuan distribusi yang baik (seperti oleh pelaku, alat transportasi, pendingin, akses jalan, waktu tempuh) sejak dari pemuatan awal di lokasi produksi dalam perjalanan sampai dinikmati oleh konsumen. Pelaku distribusi di daerah ini umumnya dilakukan oleh petani yang bertindak sebagai pedagang pengumpul. Hasil tambak dijemput oleh pengumpul di lokasi produksi, sehingga biaya transportasi dari petani tambak dalam penelitian ini dianggap nol. Sehingga saluran distri- 
busi yang dianggap paling efisien adalah secara langsung atau salurannya pendek.

Penelitian ini ingin mengetahui saluran distribusi pemasaran secara fisik dalam mendukung ketahanan pangan di daerah penelitian, melalui pedagang pengumpul.

Kerangka Pikir Teoritis. Ketahanan pangan adalah kondisi terpenuhinya kebutuhan pangan bagi rumah tangga, tercermin dari kemampuan rumah tangga untuk memenuhi kecukupan pangan anggotanya dari waktu ke waktu agar dapat hidup sehat dan mampu melakukan kegiatan sehari-hari.

Aspek produksi menghadapi persoalan inefisiensi dalam kombinasi penggunaan faktor produksi diukur dengan produktivitas. Aspek distribusi terkait dengan produk tambak yang cepat rusak, menghadapi lokasi produksi jauh dari konsumen akhir, sarana jalan sering longsor, mahalnya harga bahan bakar membuat stabilitas harga tidak menentu, dan memerlukan kemampuan manajemen.

Efisiensi teknis diukur menggunakan fungsi produksi frontier sekaligus diperoleh skala pengembalian, kemudian dilanjutkan dengan menghitung $\mathrm{R} / \mathrm{C}$ ratio. Melalui pedagang pengumpul menganalisis kinerja distribusi, dikatakan efisien apabila distribusi fisik produk tambak menggunakan institusi pemasaran relatif pendek atau langsung. Selanjutnya mengkonsumsi bukan hanya ditentukan oleh kemampuan konsumen membeli, akan tetapi oleh ketersediaan dalam jumlah yang cukup, terjangkau secara ekonomi dan tempat, dan aman dikonsumsi.

\section{METODE PENELITIAN}

Penelitian ini dilakukan untuk mengkaji kinerja budidaya tambak dalam rangka pencapaian ketahanan pangan, dari aspek produksi akan diketahui efisiensi penggunaan faktor input, skala pengembalian, dan dilanjutkan dengan menganalisis perbandingan antara penerimaan dan pembiayaan ( $\mathrm{R} / \mathrm{C}$ ratio). Pada aspek distribusi, untuk mengkaji perilaku pedagang pengumpul di lokasi penelitian, menggunakan index composite food security (ICFS) komoditas bandeng dan udang.
Metode pendekatan survei ${ }^{3}$, umumnya untuk mengumpulkan data atau informasi atas fenomena yang terjadi di lapangan. Biasanya penelitian survei jumlah populasinya besar, sehingga perlu menentukan jumlah sampel.

\section{Metode Pengumpulan Data}

Data kerat lintang (cross-sectional) dikumpulkan melalui wawancara dengan panduan kuesioner. Data primer untuk aspek produksi dikumpulkan dari petani tambak dan pedagang pengumpul. Data kependudukan (BPS, BKKBN), data statistik perikanan budidaya (DKP). Data tambak dikumpulkan berdasarkan satu siklus tanam sebelumnya, dengan mempertimbangkan lemahnya daya ingat (recall error) responden. ${ }^{4}$

\section{Penentuan Lokasi}

Di sepanjang Teluk Tomini Kabupaten Parigi Moutong terdapat 20 Kecamatan dan tidak seluruhnya dijadikan lokasi penelitian, karena beberapa alasan: (1) ada Kecamatan memiliki lahan tambak tetapi tidak produktif; (2) ada Kecamatan yang tidak memiliki lahan tambak.

Memperhatikan kondisi di lapangan dan mempertimbangkan rekomendasi dari Dinas Kelautan dan Perikanan (DKP) Kabupaten Parigi Moutong bahwa budidaya tambak di Teluk Tomini umumnya; (1) memiliki karakteristik hampir sama, maka ditetapkan Kecamatan Balinggi dan Kecamatan Parigi Selatan. (2) ditetapkan oleh Pemerintah Provinsi Sulawesi Tengah sebagai daerah pengelolaan sumberdaya alam berkelanjutan dalam area Marine and Coastal Resources Management Project (MCRMP).

\section{Metode Penarikan Sampel}

Metode Multistages sampling with purposive, berawal dari penetapan populasi aspek produksi rumah tangga perikanan (RTP), dilanjutkan dengan penarikan sampel petani pemilik tambak. Jumlah keseluruhan 157 responden, dari

3 Metode penelitian survei ini diadaptasi dari Singarimbun dan Effendi (1989), Irawan (2002), dan Arikunto (2006)

4 Diadaptasi dari Chris dan Amennvegbe dalam Poerwono (1997). 


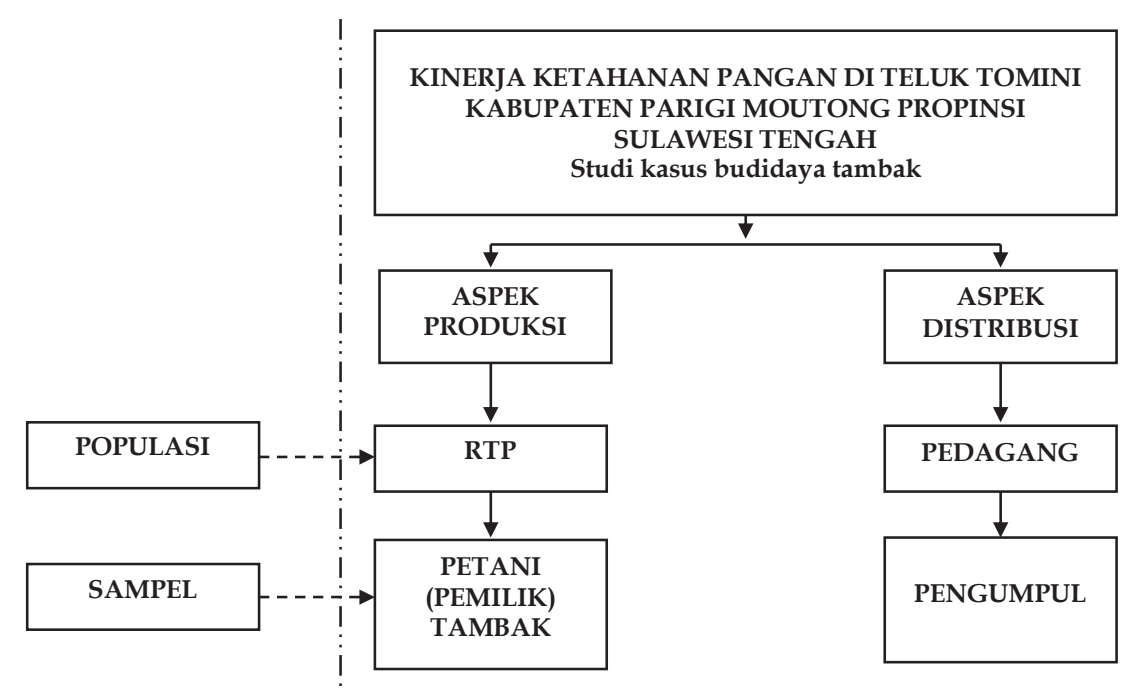

Gambar 1. Skema Penarikan Sampel

Kecamatan Balinggi 93 dan Kecamatan Parigi Selatan sebanyak 64 responden. Pada aspek distribusi sampelnya adalah pedagang pengumpul sebanyak 5 pelaku (di sensus). Skema penarikan sampel dapat dilihat pada Gambar 1.

Penarikan sampel menggunakan rumus dari Daniel dan Terrel (1989, dalam Moelyono (2007) dengan tingkat kesalahan ditetapkan 5 persen.

$n=\frac{N z^{2} p q}{d^{2}(N-1)+z^{2} p q}$

Keterangan: $\mathrm{n}$ adalah jumlah anggota sampel; $\mathrm{N}$ adalah jumlah anggota populasi; $\mathrm{z}$ adalah Nilai $z$ dengan $\alpha=0,05$ dengan nilai $z$ sebesar 1,96; $\mathrm{P}$ adalah Estimasi proporsi; $\mathrm{q}=1-\mathrm{p} ; \mathrm{D}$ adalah tingkat kesalahan $\alpha=0,05 ; \mathrm{N}-1$ adalah faktor koreksi kesalahan

\section{Definisi Operasional Variabel}

Variabel menunjukkan karakteristik yang memiliki banyak nilai dan sifat, sehingga diperlukan kesamaan pemahaman. Variabel yang digunakan dalam penelitian dapat dilihat pada Tabel 1.

\section{Metode Analisis}

Pendekatan Frontier Production Function (FPF) digunakan menghitung efisiensi penggunaan input produksi budidaya tambak. Cara ini untuk mengukur bagaimana fungsi produksi sebenarnya terhadap posisi frontiernya yang terletak pada garis isokuan. Efisiensi yang berhubungan dengan efisiensi frontiernya ingin melihat petani tambak yang maju dalam menata sumber daya yang dikuasainya sehingga diperoleh produktivitas penggunaan sumber daya yang tertinggi dibandingkan dengan petani tambak yang lain. Fattah (2000) mengatakan petani yang paling efisien tidak selalu petani tambak yang produksinya tinggi, tetapi cost-benefit-ratio atau biaya perunit yang dikeluarkannya mendapatkan hasil yang paling optimal. Budidaya tambak dikatakan efisien kalau produktivitasnya sudah berada pada batas (frontiernya).

Selanjutnya dengan menggunakan metode maximum likelihood (MLE) model stochastic frontier regression dari program pengolah data Frontier 4.1c. Fungsi produksi yang akan diestimasi adalah fungsi Cobb-Douglas sebagai berikut:

$\mathrm{Y}=\mathrm{A} \mathrm{X}_{1}{ }^{\mathrm{b} 1} \mathrm{X}_{2}{ }^{\mathrm{b} 2} \mathrm{X}_{3}{ }^{\mathrm{b} 3} \mathrm{X}_{4}{ }^{\mathrm{b} 4} \mathrm{X}_{5}^{\mathrm{b} 5} \mathrm{X}_{6}{ }^{\mathrm{b} 6} \mathrm{X}_{7}{ }^{\mathrm{b} 7} \mathrm{D}_{1-\mathrm{n}}{ }^{\mathrm{bn}} \mathrm{e}_{\mathrm{n}}$

di mana: $\mathbf{Y}$ adalah produksi $(\mathrm{kg})$ bandeng dan udang pada petani budidaya tambak; $\mathbf{A}$ adalah intercept (perpotongan); $\mathbf{X}_{\mathbf{1}}$ adalah Lahan (Ha); $\mathbf{X}_{\mathbf{2}}$ adalah Bibit (ekor); $\mathbf{X}_{\mathbf{3}}$ adalah Tenaga Kerja 


\section{Tabel 1. Definisi Operasional Variabel}

\begin{tabular}{|c|c|c|}
\hline Variabel & Ukuran & Definisi Operasional Variabel \\
\hline Produksi (Y) & $\mathrm{Kg}$ & Produksi budidaya bandeng dan udang untuk satu kali musim tanam \\
\hline Lahan $\left(\mathrm{X}_{1}\right)$ & $\mathrm{Ha}$ & Luas lahan budidaya bandeng satu kali musim tanam. \\
\hline Bibit $\left(X_{2}\right)$ & Ekor & Jumlah bibit bandeng dan udang untuk satu kali musim tanam \\
\hline Tenaga kerja $\left(X_{3}\right)$ & $\mathrm{JKOH}$ & $\begin{array}{l}\text { Jumlah jam kerja yang dialokasikan oleh seorang pekerja untuk satu } \\
\text { kali musim tanam. Secara rata-rata 5-6 jam/orang/hari selama satu } \\
\text { kali musim tanam (4 bulan) }\end{array}$ \\
\hline Pupuk $\left(\mathrm{X}_{4}\right)$ & & Penjumlahan pupuk Urea dan Sp-36 \\
\hline Urea & $\mathrm{Kg}$ & Jumlah pupuk buatan pabrik digunakan satu kali musim tanam. \\
\hline SP-36 & $\mathrm{Kg}$ & Jumlah pupuk buatan pabrik digunakan satu kali musim tanam. \\
\hline Pakan $\left(X_{5}\right)$ & $\mathrm{Kg}$ & $\begin{array}{l}\text { Jumlah pakan (jadi dan jagung rebus) digunakan untuk satu kali } \\
\text { musim tanam }\end{array}$ \\
\hline Pengalaman $\left(\mathrm{X}_{6}\right)$ & Tahun & Masa kerja melakukan budidaya bandeng \\
\hline Kapur $\left(X_{7}\right)$ & $\mathrm{Kg}$ & $\begin{array}{l}\text { Jumlah kapur karbonat } \mathrm{CaCO}_{3} \text { atau }\left[\mathrm{CaMg}\left(\mathrm{CO}_{3}\right)\right]_{2} \text { dan kapur } \\
\text { tohor/kapur aktif }(\mathrm{CaO}) \text { digunakan satu kali musim tanam. }\end{array}$ \\
\hline Teknologi $\left(D_{1}\right)$ & Dummy & $\begin{array}{l}\text { Penggunaan tehnologi } \\
\mathrm{D}=0 \text {, tidak menggunakan tehnologi (tradisional) } \\
\mathrm{D}=1 \text {, menggunakan tehnologi (tradisional plus) }\end{array}$ \\
\hline $\begin{array}{l}\text { Penyuluh perikanan } \\
\text { lapangan/PPL }\left(\mathrm{D}_{2}\right)\end{array}$ & Dummy & $\begin{array}{l}\text { Frekwensi kunjungan PPL ke lokasi tambak } \\
\mathrm{D}=0 \text {, tidak pernah berkunjung ke lokasi budidaya bandeng } \\
\mathrm{D}=1 \text {, pernah berkunjung ke lokasi budidaya bandeng. }\end{array}$ \\
\hline
\end{tabular}

$(\mathrm{JKOH}) ; \mathbf{X}_{\mathbf{4}}$ adalah Pupuk (kg); $\mathbf{X}_{\mathbf{5}}$ adalah Pakan $(\mathrm{kg}) ; \boldsymbol{X}_{\mathbf{6}}$ adalah Pengalaman (tahun); $\boldsymbol{X}_{\mathbf{7}}$ adalah Kapur (kg); $\mathbf{D}_{\mathbf{1}}$ adalah Teknologi; $\mathbf{D}_{\mathbf{2}}$ adalah PPL; $\mathbf{b}_{\mathbf{i}}$ adalah elastisitas produksi $(=\alpha)$; $\mathbf{e}_{\mathbf{n}}$ adalah faktor kesalahan pada petani budidaya tambak ke-n

Kalau persamaan ini diduga dengan frontiernya, maka nilai residunya dikomposisikan menjadi dua komponen yang independen:

$\mathrm{e}=\mathrm{v}-|\mathrm{u}|$

v mencerminkan residu yang random, sementara $\mathbf{u}$ merupakan residu yang berasal dari inefisiensi teknis. Dalam bentuk logaritma, persamaannya ditulis sebagai berikut:

$\log Y=\log A+b_{1} \log X_{1}+b_{2} \log X_{2}+v-|u|$

persamaan ini diselesaikan dengan frontier regresi (OLS regresi) yang dalam bentuk persamaan linier seperti berikut:

$$
\begin{aligned}
\log Y= & \log A+b_{1} \log X_{1}+b_{2} \log X_{2}+\ldots \ldots .+ \\
& b_{n} \log X_{n}
\end{aligned}
$$

Karena program Frontier menggunakan log normal, maka hasilnya dapat ditulis sebagai berikut:

$$
\begin{aligned}
\operatorname{Ln} Y_{i}= & c+a_{1} \operatorname{Ln} X_{1}+a_{2} \operatorname{Ln} X_{2}+a_{3} \operatorname{Ln} X_{3}+ \\
& a_{4} \operatorname{Ln} X_{4}+a_{5} \operatorname{Ln} X_{5}+a_{6} \operatorname{Ln} X_{6}+ \\
& a_{7} \operatorname{Ln} X_{7}+D_{1}+D_{2}+\eta_{i}-u_{i}
\end{aligned}
$$

Menghitung Efisiensi Teknis (ET) Petani budidaya tambak: membandingkan antara produksi sebenarnya dengan produksi maksimum (Fattah, 2000):

Efisiensi Teknis budidaya tambak per individu:

$\mathrm{ET}_{\text {individu }}=\left(\mathrm{Y}_{(\text {real })}: \hat{\mathrm{Y}}_{\text {(estimate) }}\right)$

Efisiensi Teknis budidaya tambak Kabupaten:

$\mathrm{ET}_{\text {kabupaten }}=\Sigma \mathrm{Y}_{\text {(real) })} \hat{\mathrm{Y}}_{\text {(estimate) }} / \mathrm{n}$

di mana; ET adalah efisiensi teknis; $\mathbf{Y}_{\text {(real) ada- }}$ lah besarnya produksi real; $\hat{\mathbf{Y}}_{\text {(estimate) }}$ adalah besarnya produksi yang diduga yang diperoleh melalui FPF C-D; $\mathbf{n}$ adalah jumlah sampel petani budidaya tambak.

Setelah perhitungan tersebut, dilanjutkan 
dengan menghitung pemanfaatan modal usaha tambak menggunakan revenue cost ratio. Ratio yang diperoleh dari perbandingan total penerimaan dengan total biaya adalah untuk mengetahui efisiensi pemanfaatan modal yang dipakai dalam satu siklus budidaya tambak.

\section{Menghitung Indeks Komposit Ketahanan Pangan Budidaya Tambak}

Index composite food security (ICFS) adalah indeks gabungan dari komponen ketersediaan (availability), keterjangkauan (accessibility), stabilitas (stability), dan aman (safety). ICFS ini berbeda dengan tiga metode pengitungan indeks ${ }^{5}$ lainnya. ICFS menghitung indeksnya berdasarkan kuantitas dari distribusi fisik. Pembobotannya dilihat dari jumlah distribusi fisik yang terserap oleh pasar. Untuk kepentingan tulisan ini ketahanan pangan dilihat dari komponen ICFS dengan klasifikasi sebagai berikut: Pada aspek produksi jika daya serap fisik sebesar $<0,50$, tergolong ketersediaan rendah. Pada aspek distribusi 0,50-0,80 keterjangkauan secara fisik tergolong sedang. Apabila $>0,80$ daya serap fisik produk tambak tergolong tinggi.

\section{HASIL DAN PEMBAHASAN}

Hasil estimasi fungsi produksi frontier stokastik budidaya tambak di Kabupaten Parigi Moutong, ada 3 variabel yang signifikan terhadap fungsi produksi tersebut, yaitu Lahan $\left(\mathrm{X}_{1}\right)$, Bibit $\left(\mathrm{X}_{2}\right)$, dan Tenaga Kerja $\left(\mathrm{X}_{3}\right)$ siginifikan pada $\mathrm{a}=$ $10 \%$. Hasil estimasi secara lengkap dapat dilihat pada Tabel 2.

Hasil estimasi fungsi produksi frontier stokastik persamaannya sebagai berkut:

$$
\begin{aligned}
\ln \hat{Y}= & \ln 4,7720+0,9558 \ln X_{1}+0,0782 \ln X_{2}+ \\
& 0,1340 \ln X_{3}+0,0166 \ln X_{4}-0.0301 \ln X_{5}- \\
& 0.0774 \ln X_{6}+0.1361 \ln X_{7}-0.0706 D_{1}- \\
& 0.0453 D_{2}
\end{aligned}
$$

5 Menurut Freensidy (2005), ada tiga metode penghitungan indeks suatu bursa atau industri tertentu, yaitu (i) berdasarkan harga tertimbang (price weighted); (ii) berdasarkan nilai kapitalisasi pasar (valueweighted); dan (iii) tidak tertimbang atau berbobot sama (unweighted atau equal-weights).
Tabel 2. Estimasi Fungsi Produksi Frontier Stokastik pada Budidaya Tambak di Teluk Tomini Kabupaten Parigi Moutong

\begin{tabular}{llcc}
\hline \multirow{2}{*}{ No } & \multicolumn{1}{c}{ Variabel } & \multicolumn{2}{c}{$\begin{array}{c}\text { Teluk Tomini Kabupaten } \\
\text { Parigi Moutong }\end{array}$} \\
& & Koefisien & t-ratio \\
& & 4,7720 & 1,7756 \\
& & 0,9558 & $1,7953^{*}$ \\
2 & Konstanta & 0,0782 & $2,8444^{* * *}$ \\
3 & Lahan $\left(\mathrm{X}_{1}\right)$ & 0,1340 & $3,3449^{* * *}$ \\
4 & Tenit $\left(\mathrm{X}_{2}\right)$ & 0,0166 & 0,1636 \\
5 & Pupuk $\left(\mathrm{X}_{4}\right)$ & -0.0301 & -1.1219 \\
6 & Pakan $\left(\mathrm{X}_{5}\right)$ & -0.0774 & -1.5491 \\
7 & Pengalaman $\left(\mathrm{X}_{6}\right)$ & 0.1361 & 1.5788 \\
8 & Kapur $\left(\mathrm{X}_{7}\right)$ & -0.0706 & -1.6331 \\
9 & Teknologi $\left(\mathrm{D}_{1}\right)$ & -0.0453 & -0.7549 \\
10 & PPL $\left(\mathrm{D}_{2}\right)$ & -8.5515 & \\
11 & Log Likelihood & 0.8027 & \\
12 & Mean TE & 1,2132 & \\
13 & $\sum \beta i$ & 157 & \\
14 & $\mathrm{~N}$ & & \\
\hline
\end{tabular}

Keterangan:

*** adalah signifikan pada a 1 persen; $* *$ adalah signifikan pada a 5 persen; * adalah Signifikan pada a 10 persen; $\mathrm{t}$-tabel $(\alpha=1$ persen $)=2,167$; t-tabel $(\alpha=5$ persen $)$ $=1,96 ; \quad t$-tabel $(\alpha=10$ persen $)=1,64$

Sumber: Data primer di olah (2009)

Berdasarkan persamaan ini diketahui return to scale seperti berikut:

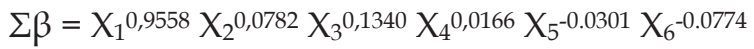

$$
\mathrm{X}_{7^{0.1361}}=1,2131
$$

Koefisien lahan sebesar 0,9558 bersifat inelastis. Artinya apabila lahan tambak luasnya ditambah sebesar 1persen akan menyebabkan peningkatan produksi tambak sebesar 0,9558 persen. Koefisien bibit sebesar 0,0782 bersifat inelastis. Artinya apabila penggunaan bibit ditambah sebesar 1 persen akan menyebabkan peningkatan produksi tambak sebesar 0,0782 persen. Koefisien tenaga kerja mencapai 0,1340. Apabila penambahan tenaga kerja 1persen akan menyebabkan peningkatan produksi tambak sebesar 0,1340 persen.

\section{Efisiensi Teknis}

Rerata efsiensi teknis di Kabupaten Parigi Moutong mencapai 0,803 tergolong belum 


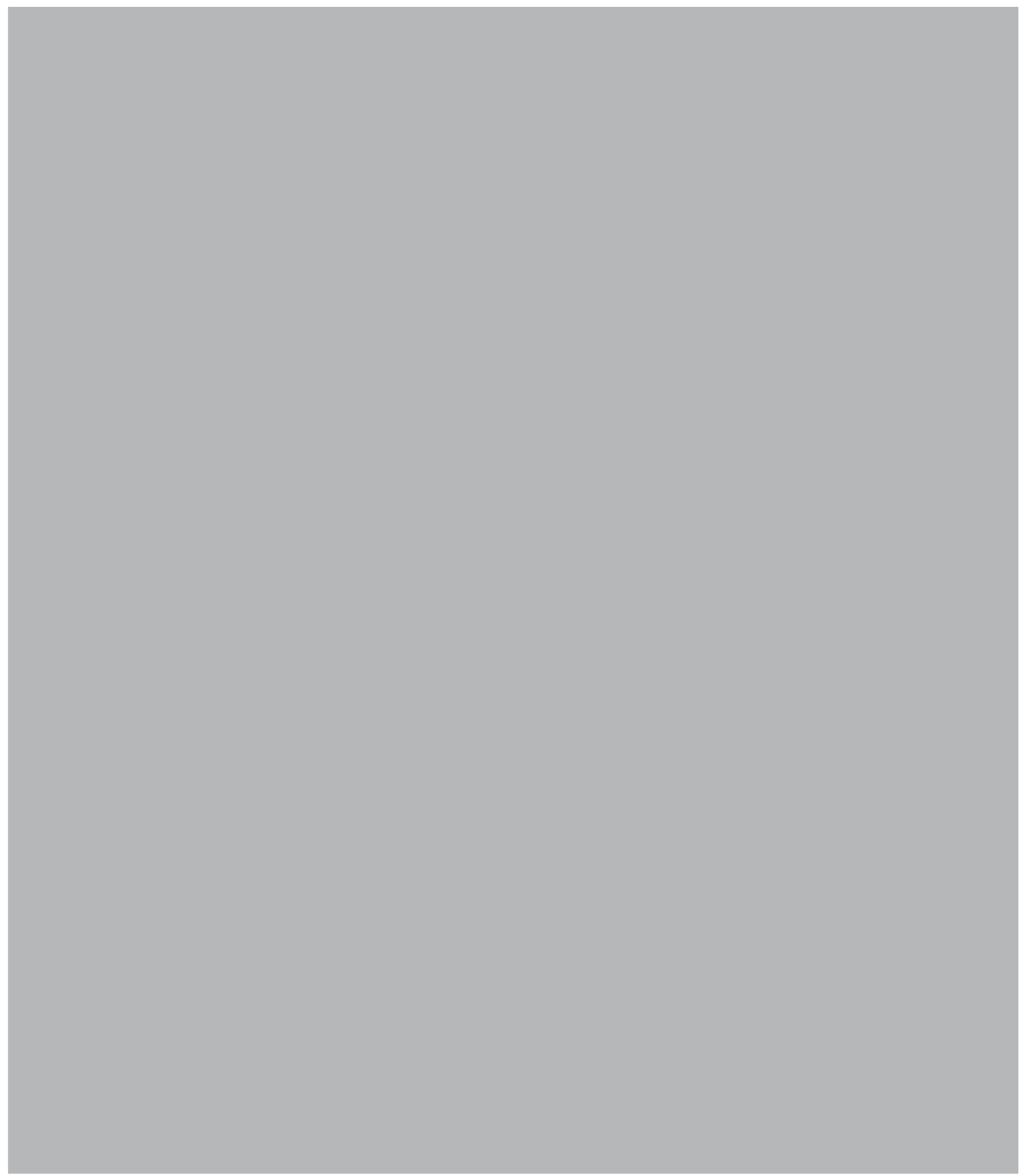

4.103.951.000 dengan total biaya sebesar Rp1.367.346.000. Membandingkan total penerimaan dengan biaya diperoleh $\mathrm{R} / \mathrm{C}$ ratio sebesar 3,00. Ratio perbandingan ini menunjukkan pengeluaran Rp1 akan memperoleh manfaat Rp3.

Angka sebesar 0,148 menunjukkan ketersediaan produk tambak yang mampu diserap oleh pasar internal Kecamatan. Artinya secara

\section{SIMPULAN}

Hasil perhitungan menunjukkan bahwa lahan, bibit, dan tenaga kerja mempunyai hubungan yang positif dan berpengaruh nyata terhadap nilai produksi. Secara teknis $(0,803)$ belum efisien, produksi tambak di Kabupaten Parigi 
Moutong masih dapat ditingkatkan, melalui optimalisasi penggunaan input produksi. Indikasi ini dapat dilihat dari nilai IRS $(1,2132)$ dan nilai $R / C$ rationya (3) cukup besar.

Perbandingan nilai $\mathrm{R} / \mathrm{C}$ ratio $(3: 1)$, memperkuat argumentasi bahwa perilaku oligopolistik berpotensi menimbulkan kerawanan pangan komoditas bandeng dan udang di lokasi penelitian. Hal ini dapat dilihat dari komponen ketersediaan untuk pasar internal Kecamatan masih dalam satu Kabupaten, daya serapnya secara fisik hanya sebesar 0,148 dari total distribusi. Secara fisik produk tambak ini telah memenuhi permintaan pasar internal Kecamatan di lokasi produksi, sehingga komoditas ini memiliki ketahanan pangan. Demikian pula dengan keterjangkauan secara ekonomi dan tempat $(0,216)$ menunjukkan pasar eksternal Kecamatan masih dalam satu Kabupaten, terpenuhi secara fisik. Ini menandakan bahwa komoditas bandeng dan udang memiliki ketahahan pangan di daerah penelitian.

Distribusi fisik produk tambak di lokasi penelitian memiliki ketahanan pangan, karena mendapat dukungan saluran distribusi pemasaran, baik langsung maupun tidak langsung.

\section{DAFTAR PUSTAKA}

Pasaribu, Ali Musa. 2004. Kajian Sistem Modular pada Usaha Tani Ikan Bandeng (Chanos-Chanos, forskal) di Sulawesi Selatan. Jurnal Pengkajian dan Pengembangan Teknologi Pertanian Vol.7, No.2, Juli: Hal. 187-192.

Darwanto, Dwidjono H. 2005. Ketahanan Pangan Berbasis Produksi dan Kesejahteraan Petani. Ilmu Pertanian Vol. 12 No. 2.

Welirang, Franciscus. 2007. Revitalisasi Republik Perspektif Pangan dan Kebudayaan. Jakarta: Penerbit Grafindo Khazanah Ilmu.

Hermanto. 2007. Pengelolaan Budidaya Tambak Berwawasan Lingkungan. (Widyaiswara BPPP Belawan-Medan, 30 Desember). http://www.budidaya.net. Di akses tanggal 22 oktober 2008.

Nainggolan, Kaman. 2008. Penguatan Strategi
Ketahanan Pangan Nasional. CIDES. (27 Peberuari. http://www.cidesonline.org. Di akses tanggal 12 nopember 2008.

Yusuf, Liswarti, dkk. 2008. Teknik Perencanaan Gizi Makanan. Jilid 1. Buku Sekolah Elektronik

Singarimbun, Masri dan Sofyan Effendi. 1989. Metode Penelitian Survey. Edisi Revisi. Jakarta: LP3ES.

Partomo, Tiktik Sartika 2008. Ekonomi Industri. Surabaya: Penerbit. Inti Prima

Smith, Ian R. 1981. Microeconomics of Existing Aquaculture Production Systems: Basic Concepts and Definitions. Aquaculture Economic Research in Asia Proceedings of a workshop held in Singapore, 2-5 June 1981 International Center for Living Aquatic Resources Management (ICLARM) International Development Research Centre (IDRC).

Sugiarto, Tedy Herlambang, Brastoro, Rachmat Sudjana, dan Said Kelana. 2007. Ekonomi Mikro Sebuah Kajian Komprehensif. Penerbit. PT. Gramedia Pustaka Utama.

Supadi. 2004. Ketahanan Pangan dan Impor Beras Berkelanjutan. Pusat Penelitian dan Pengembangan Sosial Ekonomi Pertanian. Badan Penelitian dan Pengembangan Pertanian Departemen Pertanian. Maret. caser@indosat.net.id. Diakses tanggal 22 nopember 2008.

Efendi, Yempita. 2008. Ingin Sehat "Makan Ikan" Setiap Hari. http://fpik.bunghatta.info/news.php?extend.42 dan http://www.kompas.com/swara/index.htm. Diakses 11 desember 2008.

Dinas Kelautan dan Perikanan Sulawesi Tengah, 2006. Laporan statistik Perikanan Budidaya 2005. Provinsi Sulawesi Tengah.

Dinas Kelautan dan Perikanan Sulawesi Tengah, 2006, Laporan statistik Perikanan Tangkap 2005. Provinsi Sulawesi Tengah.

Departemen Kelautan dan Perikanan, 2005. Jakarta. (http://www.brkp.dkp.go.id)

Direktorat Jendral Perikanan Budidaya, 2005. 
Pusdatin DKP.2008. Target Produksi Perikanan Budidaya Tak Tercapai. (Antara News)

Statistik Perikanan Budidaya, DKP, 1999-2004

Statistik Perikanan Budidaya, DKP 2005 dan 2007

Komariah, A. Tansil. 1996. Usaha Budidaya Tambak Udang Di Kabupaten Sidoarjo Hubungan antara Lingkungan dengan Usaha Tambak. Program Pascasarjana IPB (tesis) tidak diterbitkan.

Fattah, Madukallang. 2000. Perilaku Ekonomi Masyarakat Pedesaan. Study Kasus Pada
Dua Desa Masyarakat Suku Tolare Kabupaten Donggala Sulawesi Tengah. (Disertasi). Program Pasca Sarjana Universitas Hasanuddin. Makassar.

Moelyono, Mauled. 2007. Peran Modal Sosial Dalam Memoderasi Pengaruh Jaringan Usaha Dan Pembelajaran Organisasi Terhadap Kinerja UKM Sektor Manufaktur Di Kota Palu. Januari. (Disertasi), Tidak Diterbitkan Program Pascasarjana Universitas Negeri Malang. 